\title{
Wymogi i nakazy dotyczace noszenia masek ochronnych
}

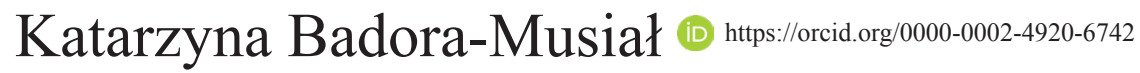

Zakład Polityki Zdrowotnej i Zarządzania, Instytut Zdrowia Publicznego, Wydział Nauk o Zdrowiu, Uniwersytet Jagielloński, Collegium Medicum

Adres do korespondencji: Katarzyna Badora-Musiał, Zakład Polityki Zdrowotnej i Zarządzania, Instytut Zdrowia Publicznego, ul. Grzegórzecka 20, 31-531 Kraków, kasia.badora@uj.edu.pl

\section{Absract}

In the absence of effective drugs that could be used in the treatment of infection caused by SARS-CoV-2, behavioral methods of preventing infection have become important in counteracting the epidemic, including wearing protective masks. A historical overview of the epidemic and the introduction of the mask order allows an epidemic to be better understood not only as a biological event, but also as a social process. Many countries have enforced the wearing of masks in public despite conflicting opinions about whether their use could prevent transmission of the coronavirus from one person to another. In Poland, the content of the official message on the effectiveness of wearing masks was changing, ultimately introducing the obligation to cover the mouth and nose with masks or an element of clothing in generally accessible places.

Key words: Coronavirus, COVID-19, face masks, personal protective equipment, public health

Stowa kluczowe: Koronawirus, COVID-19, maseczki, środki ochrony indywidualnej, zulrowie publiczne

\section{Wprowadzenie}

11 marca 2020 r. epidemia wirusa SARS-CoV-2 (należącego do grupy koronawirusów), który powoduje chorobę COVID-19, została uznana przez Światową Organizację Zdrowia za pandemię [1]. Główną drogą przedostania się do organizmu wirusów oddechowych, takich jak SARS-CoV-2, jest nos, oczy i usta (tzw. ,strefa T") [2]. W związku z tym, aby zapobiec transmisji wirusa, ważne jest podejście wielopłaszczyznowe obejmujące zarówno środki farmakologiczne (np. szczepienia), jak i behawioralne (np. mycie rąk, dystans społeczny czy noszenie maseczek) [3]. Wobec braku skutecznych leków, które mogłyby być zastosowane w leczeniu infekcji spowodowanej tym koronawirusem, znaczenia w przeciwdziałaniu epidemii nabrały właśnie behawioralne metody zapobiegania zakażeniu, zwłaszcza pozornie proste działania związane $\mathrm{z}$ utrzymywaniem higieny, jak częste i staranne mycie rąk, a także utrzymywanie społecznego dystansu, czyli unikanie fizycznej bliskości z ludźmi [4]. Najbardziej popularnym narzędziem osobistej ochrony zabezpieczającym przed infekcją okazały się chroniące twarz maseczki. Jednak skuteczność ich noszenia w zapobieganiu infekcjom układu oddechowego podczas epidemii była często kwestionowana [5, 6]. Wiele autorytetów i instytucji zmieniało zdanie co do zasadności ich noszenia. Ponadto niedobór masek ochronnych podczas pandemii koronawirusa stał się symbolem kruchości współczesnej medycyny i zdrowia publicznego. Ludzie masowo sami zaczęli szyć maseczki, przekazując znaczną ich część pracownikom służby zdrowia. WHO oszacowało, że na całym świecie potrzeba miesięcznie 89 milionów masek medycznych, a także 76 milionów rękawiczek jednorazowych, 1,6 miliona okularów i przyłbic [7]. Połączenie zwiększonego zapotrzebowania na środki ochrony osobistej i dużych zakłóceń na rynku globalnym utrudniło praktycznie wszystkim krajom uzyskanie tych środków na własne potrzeby.

\section{Historia noszenia masek ochronnych}

Noszenie masek od zawsze związane było z ukrywaniem, zmianą tożsamości lub osłoną, czy to w szczególnych okolicznościach rytuału lub teatru, czy to w celu dokonania zbrodni lub zawoalowania kobiet. W przeciwieństwie do tych zastosowań maski medyczne nie służą do chowania się, lecz ochrony. Zachowują tożsamość osoby noszącej, zachęcając raczej do solidarności niż do segregacji [8].

Maski ochronne były czasami stosowane już podczas rzymskich turniejów gladiatorów. $\mathrm{Z}$ dowodów archeologicznych wynika, że miały one na celu nie tylko chronić, ale także sprawiały, że osoba je nosząca wyglądała bardziej przerażająco. W średniowiecznej Europie i Japonii żołnierze i samurajowie nosili podobnie okrutnie wyglądające zbroje, rozciągające się na maski. W XVI wieku 
kobiety nosiły osłony na twarzy (visard) w celu ochrony przed poparzeniem słonecznym i utrzymania bladości skóry [9].

Maseczki ochronne jednak towarzyszyły przede wszystkim pracownikom medycznym. Symbolem czarnej śmierci stali się lekarze w charakterystycznych, przypominających ptasie dzioby maskach. Dziób takiej maski wypełniany był słomą (działanie filtrujące) oraz ziołami (niwelowanie nieprzyjemnego zapachu) i miał chronić przed zgniłym powietrzem wokół chorego, które uważano za przyczynę przenoszenia się zarazy. Historycy spierają się o to, czy maski były stosowane już w XIV wieku przez medyków zarazy, czy jako element stroju ochronnego wprowadził je dopiero w XVI wieku wybitny medyk Charles de Lorme [10].

Maski ochronne, które miały zapobiec rozprzestrzenianiu się choroby i były noszone zarówno przez personel medyczny, jak i ogół społeczeństwa, zostały opracowane w czasie dżumy mandżurskiej w latach 1910-1911. Lekarz Wu Lien-Teh (Wu Liande), który został powołany do kierowania działaniami przeciwko zarazie, twierdził, że choroba przenoszona jest przez kontakt powietrzny, dlatego uważał, że noszenie maseczek przez ogół społeczeństwa (a nie tylko przez kadrę medyczną) pomoże w zwalczeniu choroby [11].

Z kolei podczas pandemii grypy w latach 1918-1919 noszenie masek stało się obowiązkowe dla policji, pracowników medycznych, a nawet mieszkańców niektórych amerykańskich miast, chociaż ich stosowanie było często kontrowersyjne [12].

\section{Powody noszenia maseczek ochronnych}

Zrozumienie epidemii nie tylko jako zdarzeń biologicznych, ale także jako procesów społecznych jest kluczem do jej skutecznego powstrzymania. Członkowie społeczności noszą maski nie tylko w celu zwalczania chorób, ale także aby pokazać, że chcą się trzymać razem i wspólnie radzić sobie ze zmorą zarazy.

W niektórych częściach Azji wszyscy domyślnie noszą maseczki - jest to zachowanie uważane za bezpieczniejsze i bardziej rozważne. W Chinach, Hongkongu, Japonii, Korei Południowej, Tajlandii i na Tajwanie przyjmuje się, że każdy może być nosicielem wirusa, nawet zdrowi ludzie, dlatego też w duchu solidarności należy chronić innych przed sobą. W Indonezji i na Filipinach, gdzie istnieje podejrzenie, że jest wiele niepotwierdzonych przypadków zakażenia, większość ludzi w dużych miastach nosi maseczki, aby uchronić się przed innymi. W wielu z tych krajów noszenie maski było kulturową normą jeszcze przed wybuchem epidemii koronawirusa (były wykorzystywane w różnych kryzysach zdrowia publicznego, np. ze względu na zanieczyszczenie powietrza czy choroby, takie jak SARS) [13].

To właśnie epidemia SARS w latach 2002-2003 doprowadziła do masowego używania maseczek jako osobistej ochrony antywirusowej w Chinach i innych krajach Azji Wschodniej (według niektórych źródeł ponad 90\% mieszkańców Hongkongu nosiło je podczas epidemii SARS). Jak zauważył wówczas socjolog
Peter Baehr: „«Kultura maskowania» sprzyja poczuciu wspólnego losu, wzajemnego zobowiązania i obowiązku obywatelskiego. Skupia ludzi stojących przed wspólnym zagrożeniem i pomaga złagodzić jedno z drugorzędnych zagrożeń związanych z epidemią: anomię lub załamanie norm społecznych. (...) Noszenie maski to rytuał społeczny" [14].

Wśród Europejczyków czy Amerykanów noszenie maseczek ochronnych jednak nie było dotychczas popularne. Pierwsze nakazy używania tego rodzaju środków ochronnych pojawiły się już w czasie wspomnianej pandemii grypy w latach 1918-1919. W USA poszczególne stany podejmowały różne inicjatywy w celu zapobiegania rozprzestrzenianiu się choroby (m.in. zamykano szkoły, kościoły czy miejsca rozrywki, zachęcano do używania chusteczek do nosa, a także wymagano noszenia maseczek w miejscach publicznych). Amerykański Czerwony Krzyż w swoich ulotkach informował, że „mężczyzna, kobieta lub dziecko, którzy nie będą nosić maseczek, są niebezpiecznymi obibokami (ang. slacker)" [15]. Ponadto poczucie wojennego obowiązku (środki ochrony przeciw grypie zostały bowiem określone jako ochrona żołnierzy przed śmiertelnym wybuchem) - i właśnie strach przed byciem ocenianym w ten sposób zmotywowały ludzi do przestrzegania rozkazów maskowania w miastach takich jak San Francisco, Seattle, Denver i Phoenix. Pomimo aprobaty dla nakazu noszenia maseczek przez znaczną część obywateli pojawiały się także narzekania, że maski są niewygodne, nieskuteczne, niekorzystne dla biznesu oraz że nakaz ich noszenia narusza wolność obywatelską. Według raportu z listopada 1918 r. z Garland City Globe w Utah „Przeciętny mężczyzna nosił maskę przewieszoną przez szyję, dopóki nie zobaczył policjanta, a większość ludzi miała wycięte w nich otwory, przez które można było wsunąć cygara i papierosy" [16].

Po zakończeniu wojny, kiedy argument o bezpieczeństwie żołnierzy nie był już istotny, zaczęły pojawiać się nawet ruchy sprzeciwiające się temu nakazowi (jak np. Anti-Mask League w San Francisco). Wobec „buntowników" stosowano kary grzywny, więzienia, a także wydrukowania ich nazwiska w gazecie. Zatrudniono specjalną policję, zajmującą się grypą, która np. wychwytywała dzieci bawiące się na ulicach czy osoby całujące się [16]. Eugene C. Caley był pierwszym mężczyzną w Oakland w Kalifornii, który został aresztowany (1 listopada 1918 r.) za brak maski. Zwolniono go za kaucją, chociaż podobne wykroczenia w San Francisco kończyły się karą do 10 dni więzienia [17].

W Wielkiej Brytanii noszenie maseczek jako środka ostrożności było zalecane tylko w dużych miastach, a następnie tylko dla niektórych grup, takich jak pielęgniarki grypy w Manchesterze czy Liverpoolu. Ważne pytania dotyczące skuteczności noszenia maseczek pojawiły się dopiero w marcu 1919 r., i to tylko w środowisku naukowym. Większość brytyjskich naukowców uznała wówczas używanie maseczek ochronnych za „wątpliwe lekarstwo" [17].

Amerykańska historyczka Nancy Bristow jednak zauważa, że społeczności, które wprowadziły silniejsze 
środki ochrony, „spłaszczyły krzywą i miały niższą śmiertelność", jednak w tamtych czasach ta statystyka nie była za bardzo widoczna [17].

\section{Rodzaje maseczek ochronnych}

W związku z popularnością używania maseczek w czasie pandemii koronawirusa $\mathrm{w}$ jednym $\mathrm{z}$ proponowanych w USA rozróżnień wskazywano trzy ich rodzaje: maseczki wytwarzane amatorsko w domu, maseczki chirurgiczne i maseczki typu N95 respirator [18].

Wskazanie pierwszego rodzaju masek jako wartościowego sprzętu było zapewne wymuszone niedostatecznym zaopatrzeniem w wyroby wytworzone profesjonalnie, ale Centra Kontroli i Prewencji Chorób (Centers for Disease Control and Prevention, CDC) traktowały je na tyle poważnie, że zamieściły instrukcję ich szycia [19], a w propagowanie tej aktywności zaangażował się osobiście naczelny lekarz kraju dr admirał Jerome Adams [20].

W polskiej telewizji pokazano skuteczność filtrowania aerozolu masek wykonanych $\mathrm{z}$ różnych materiałów, łącznie z workiem do odkurzacza, który okazał się nadspodziewanie skuteczny [21]. Jednak osłony przygotowane z nieodpowiednich tkanin, jak szaliki, już tej skuteczności nie potwierdzały. Stosowanie takich maseczek zalecano osobom w zasadzie zdrowym, niewykazującym żadnych symptomów choroby, ale u których możliwy był bezobjawowy przebieg choroby, a więc osobom, które mogły być potencjalnymi nosicielami. Z założenia maseczki te nie miały zatem chronić osoby, która je nosiła, ale ludzi z otoczenia, nieświadomie narażonych na ekspozycję.

Bardzo podobne zastosowanie mają maseczki chirurgiczne, również używane dla ochrony osób znajdujących się w otoczeniu osoby, która ją nosi [22]. Będąc sprzętem profesjonalnym, maseczka chirurgiczna jest skuteczna w filtrowaniu na zewnątrz cząstek mogących ewentualnie zawierać wirusy, a także częściowo chroni osobę noszącą maskę, zmniejszając przedostawanie się cząstek zakaźnych, również do wewnątrz, jednak nie dotyczy to raczej koronawirusa [23].

Maski oznaczane symbolami FFP (ang. filtering facepiece mask), i odpowiednio FFP1, FFP2 lub FFP3, są przeznaczone dla personelu medycznego, mającego kontakt $\mathrm{z}$ pacjentami zakażonymi lub $\mathrm{z}$ podejrzeniem zakażenia SARS-CoV-2 [24]. Kolejne wartości liczbowe określają wzrastającą skuteczność filtrowania zawartych w powietrzu potencjalnie szkodliwych cząstek. Maseczki te są odpowiednikiem maski określonej w zaleceniach CDC jako N95 respirator. Maseczki FFP1, FFP2 i FFP3, W zależności od rodzaju, nie przepuszczają odpowiednio: $80 \%$, 94\% lub 99\% cząstek szkodliwych aerozoli (o rozmiarze od $300 \mathrm{~nm}$ ). Maseczki te są w zasadzie przeznaczone do jednorazowego użytku, ale w sytuacjach niedoboru Europejskie Centrum ds. Zapobiegania i Kontroli Chorób (European Centre for Disease Prevention and Control, ECDC) dopuściło ich sterylizację [25].

W ramach Unii Europejskiej wprowadzono standardy pozwalające oceniać jakość sprzętu ochrony osobistej i zasady przeprowadzania jego oceny, łącznie z graficznym znakiem zgodności WE [26]. W literaturze można znaleźć wyniki ocen prowadzących do porównania walorów ochronnych i użytkowych różnego rodzaju sprzętu, dostarczanego przez różnych wytwórców i stosowanego w różnych krajach [27].

\section{Informacje}

Na poziomie informacji profesjonalnej nie było wątpliwości, że maseczki ochronne powinny być bezwzględnie noszone przez pracowników przede wszystkim sektora zdrowotnego, którzy mają bezpośredni kontakt z chorymi. Jeśli rekomendacja ta nie była w niektórych sytuacjach przestrzegana, to wynikało to $\mathrm{z}$ niedostatecznej ilości dostępnego sprzętu, co zresztą było dostrzegane przez międzynarodowe gremia, godzące się na jego kilkukrotne używanie, wbrew fabrycznym zaleceniom. Także osobom chorym, w tym bezobjawowo, bezwzględnie zalecano noszenie masek chroniących otoczenie. Przedmiotem niejasności, niekiedy kontrowersji, pozostawał natomiast postulat powszechnego noszenia masek przez ogół ludności. O ile obrazy ilustrujące sytuację w krajach azjatyckich pokazywały powszechne ich noszenie, o tyle komunikaty przekazywane przez przedstawicieli władzy były znacznie mniej jednoznaczne. Charakterystyczna pod tym względem była postawa członków rządu USA, którzy nie nosili masek w miejscach publicznych czy podczas prasowych briefingów, a w prasowych komentarzach pojawiła się nawet teza, że noszenie maseczek może świadczyć o braku męskości [28], co mogłoby zmniejszyć szansę Donalda Trumpa na reelekcję [29]. W tym samym czasie pracownicy Białego Domu zostali zobowiązani do noszenia masek, także w związku z kwarantanną trzech najważniejszych ekspertów doradzających w sprawach pandemii COVID-19 [30] ${ }^{1}$. Jednocześnie wielu ekspertów jednoznacznie głosiło postulat noszenia maseczek przez wszystkich. Na przykład dr George Gao, szef chińskiego Centrum Kontroli i Prewencji Chorób, główny dowodzący walką z epidemią w tym kraju, twierdził, że wszyscy, którzy wychodzą z domów, muszą nosić maseczki, które nie mają służyć ochronie tych, którzy je noszą w miejscach publicznych [31]. Mają natomiast chronić innych przed potencjalnymi zakażonymi koronawirusem SARS-CoV-2.

Warto wskazać, że ostatnio ogłoszone wyniki badań potwierdzają skuteczność masek jako metody zmniejszającej zagrożenie rozprzestrzenianiem się wirusa COVID-19 [32]. Co interesujące, badacze ustalili, że nawet prosta, choć dobrze, by była wielowarstwowa, maseczka chroni nie tylko otoczenie, ale także osobę, która ją nosi. Potencjalnie jest to ważny i przekonujący argument do wykorzystywania przez wszystkich, którzy opowiadają się za jej stosowaniem.

W Polsce treść oficjalnego przekazu w sprawie maseczek ulegała zmianie. 26 lutego 2020 r., a więc zanim pojawiły się pierwsze zachorowania w kraju, minister zdrowia Łukasz Szumowski wyrażał wątpliwości co do ich przydatności i twierdził, że nie ma podstaw, by zalecać ich powszechne noszenie $[33]^{2}$. Kontynuując 
wątek, powiedział: „Kiedyś w Chinach i całym świecie azjatyckim noszono je głównie z powodu smogu i pewnej kultury, która tam jest. WHO nie zaleca. Eksperci nie zalecają" [34]. Jednak opinie uzasadniające zdystansowany stosunek do zasady powszechnego noszenia masek uległy zmianie i chociaż minister nigdy nie przedstawił argumentów uzasadniających zmianę swojego stanowiska, od 16 kwietnia 2020 r. praktycznie wszyscy zostali zobligowani do ich stosowania [35]. Rzecznik Ministerstwa Zdrowia przypomniał, że „maseczka ma chronić nie nas przed innymi, ale innych przed nami. Ma chronić przed zakażeniem od nas, jeżeli bylibyśmy nosicielem" [36]. Dodajmy, że spełnienie tego obowiązku miało polegać niekoniecznie na noszeniu maseczki, ale na przesłonięciu nosa i ust dowolną tkaniną. Jak powiedział minister Szumowski: „Nie mówimy, że musi to być maseczka, może to być chustka, szalik", bo ważny był cel stosowania [37].

Czas obowiązywania wymogu noszenia maseczek nie został z góry określony, ale Szumowski deklarował, że może to trwać do czasu wynalezienia szczepionki [38], co w praktyce może potrwać nawet dwa lata [39]. Niezależnie jednak od tej deklaracji w Internecie przedstawiono następujący argument, uznany za naukowy: „Nie ma potwierdzonego naukowo dowodu dającego podstawy do stwierdzenia, że noszenie masek jest nieskuteczne. Przeciwnie (...), najnowsze odkrycia biologiczne dotyczące wnikania wirusa SARS-CoV-2 do tkanek ludzkich (...) sugerują, że głównym mechanizmem przenoszenia wirusa nie są drobne aerozole, ale duże kropelki, a zatem noszenie masek chirurgicznych przez wszystkich gwarantuje wyższy poziom ochrony" $[40]^{3}$. Mimo logicznej pokrętności wywodu - badania poszukujące zaprzeczenia - przedstawiony argument mógł okazać się przydatny w popularyzowaniu racjonalnych zachowań.

Jednoznacznego odbioru postulatu powszechnego używania masek nie ułatwiały komentarze głównego inspektora sanitarnego Jarosława Pinkasa, który jasno wypowiedział się, że noszenie masek i maseczek ochronnych nie chroni przed zarażeniem się koronawirusem: „Maseczki nie chronią przed zarażeniem koronawirusem! Noszenie ich przez osoby zdrowe jest kompletnie bezsensowne. Są one dla osób chorych właśnie po to, aby nie zarażały innych. Natomiast nie ma żadnego powodu, aby w naszym klimacie, w naszym kraju nosiły je osoby zdrowe" - thumaczył. Pinkas dodał, że w razie potrzeby GIS wyda odpowiedni komunikat na ten temat oraz że „obecnie jest to tylko nabijanie kabzy osobom, które wykorzystując zaniepokojenie epidemią koronawirusa, podnoszą ceny" [41].

Podobne stanowisko wyraził również doradca Głównego Inspektoratu Sanitarnego - Włodzimierz Gut. W wywiadzie udzielonym 28 lutego 2020 r. powiedział, że „maseczki są groźniejsze niż ich brak, (...) wystarczy, że personel medyczny nakłada je chorym na czas transportu" [42]. W relacji $\mathrm{z}$ wypowiedzi udzielonej kilka dni później opinię eksperta dotyczącą skuteczności noszenia maseczek przez wszystkich określono jako sceptyczną [43]. Przytoczono jego słowa: „...maseczki powinien nosić chirurg, żeby nie zakazić pola operacyjnego, chory, żeby nie zakazić tych, co będą przechodzili obok niego, personel, który zajmuje się chorymi. Innym takie maseczki są zbędne". Z kolei 6 marca 2020 r. potwierdził on, że maseczka nie jest wskazana dla osób, które nie są zakażone koronawirusem [44]. Jednocześnie sposób sformułowania komentarzy pozostawiał niepewność co do ich przeznaczenia i celu. Jeśli uznać, że maseczka ma chronić otoczenie, a nie noszącą ją osobę, to z zalecenia, by „maseczki nosili ci, którzy wchodzą w strefę skażenia" - jak powiedział Gut - mogło wynikać, że jest to środek osobistej ochrony noszącego [45]. Ten sam ekspert stwierdził, że powszechne noszenie maseczek jest „niezbyt sensowne” także dlatego, że trwałość (skuteczność) maseczki przeciętnej jakości wynosi 20 minut, a więc jej dłuższe używanie mija się z celem [46]. Warto odnotować, że opinia ta została przedstawiona $\mathrm{w}$ dzień po wejściu $\mathrm{w}$ życie nakazu powszechnego noszenia maseczek w miejscach publicznych.

Od 30 maja 2020 r., kiedy Polska wkroczyła w fazę „odmrażania"/otwierania się, obowiązek zasłaniania ust i nosa w przestrzeni otwartej został uchylony pod warunkiem możliwości zachowania dwóch metrów odległości od innych. Jednak w niektórych przestrzeniach zamkniętych, między innymi sklepach, kościołach czy środkach transportu publicznego, zakaz utrzymano [47].

\section{Sytuacja prawna wprowadzenia nakazu noszenia maseczek}

W związku ze stanem epidemii, począwszy od 31 marca 2020 r., wprowadzane są kolejnymi rozporządzeniami Rady Ministrów zakazy, nakazy i ograniczenia. Jednym z nich jest obowiązek zasłaniania ust i nosa za pomocą maseczek lub elementu odzieży w miejscach ogólnodostępnych. Zakaz ten pojawił się $\mathrm{w}$ rozporządzeniu wydanym 10 kwietnia 2020 r. z mocą obowiązującą od 16 kwietnia 2020 r. [48]. Zanim wszedł w życie, został uszczegółowiony, a do przepisu wprowadzono wiele wyjątków (§ 18 rozporządzenia z 15 kwietnia 2020 r. [49], zaktualizowany rozporządzeniem z 2 maja 2020 r. [50]).

W praktyce obowiązek sprowadza się do powszechnego używania osłony twarzy, gdy wychodzimy z domu w przestrzeń ogólnodostępną. Wyjątki, choć liczne, dotyczą specyficznych wypadków, uzależnionych między innymi od czynników zawodowych, miejsca przebywania danej osoby (np. las) czy uwarunkowań zdrowotnych uniemożliwiających bezpieczne noszenie maski [51].

$\mathrm{Z}$ rozporządzenia Rady Ministrów wynika jednoznacznie, że wprowadzone ograniczenie traktowane jest jako zabieg „profilaktyczny”. Mówi o tym chociażby dodanie do tytułu rozdziału 8 znowelizowanego rozporządzenia określenia „oraz obowiązek stosowania środków profilaktycznych". Restrykcje maseczkowe powiązane zostały z delegacją ustawową z art. 46b pkt 4 Ustawy $\mathrm{z}$ dnia 5 grudnia 2008 r. o zapobieganiu oraz zwalczaniu zakażeń i chorób zakaźnych u ludzi [52]. Porównanie zakresu rozporządzenia i delegacji ustawowej prowadzi 
do jednoznacznego wniosku, że wprowadzona restrykcja może odnosić się wyłącznie do osób chorych i podejrzewanych o zachorowanie. W pozostałym zakresie obowiązek zasłaniania ust i nosa przez ,wszystkich” nie ma podstaw prawnych [51].

W związku z wprowadzaniem zakazów i nakazów rzecznik praw obywatelskich Adam Bodnar przedstawił premierowi Mateuszowi Morawieckiemu swe uwagi. RPO zauważył, że nawet w stanach nadzwyczajnych, o których mowa w Konstytucji, zakres ograniczeń konstytucyjnych wolności i praw musi wynikać z ustawy. Mimo przesłanek, o których mowa w art. 230 Konstytucji, w zakresie zwalczania choroby zakaźnej wywołanej wirusem SARS-CoV-2 - a więc szczególnego zagrożenia dla bezpieczeństwa obywateli i porządku publicznego - nie zdecydowano się dotychczas na wprowadzenie stanu nadzwyczajnego. Uchwalono natomiast Ustawę z 2 marca 2020 r. o szczególnych rozwiązaniach związanych z zapobieganiem, przeciwdziałaniem i zwalczaniem COVID-19, innych chorób zakaźnych oraz wywołanych nimi sytuacji kryzysowych [53].

Bodnar zauważył, że opisany stan rzeczy może powodować sytuację, w której nie będzie możliwe pociągnięcie do odpowiedzialności za wykroczenie osób, które nie przestrzegają tak ustanowionych zakazów i nakazów, choć taką odpowiedzialność niewątpliwie powinny ponieść. W przypadku rozporządzenia każdy sąd ma prawo odmówić jego zastosowania, jeśli stwierdzi, że wydano je z przekroczeniem granic upoważnienia ustawowego bądź pozostaje ono w hierarchicznej niezgodności z aktami wyższego rzędu. Sędziowie podlegają bowiem tylko Konstytucji i ustawom - nie aktom wykonawczym wydanym z naruszeniem ustawy lub Konstytucji [54].

Brak odpowiednich podstaw prawnych był powodem decyzji Sądu Rejonowego w Kościanie z dnia 3 czerwca 2020 r. odmowy wszczęcia postępowania przeciwko osobie, co do której Komendant Powiatowy Policji w Kościanie zażądał ukarania za czyny z art. 54 kw, polegające na naruszeniu zakazu przemieszczania na terenie Rzeczypospolitej Polskiej w dniu 19 kwietnia 2020 r. oraz niezastosowaniu się do obowiązku zakrywania ust i nosa w miejscu ogólnodostępnym [55].

Według stanu na 31 maja 2020 r. policja od chwili wprowadzenia przepisów, czyli od 16 kwietnia 2020 r., wobec osób łamiących nakaz noszenia maseczek:

- 39885 razy zastosowała pouczenia, zwrócenie uwagi, ostrzeżenia lub inne środki oddziaływania wychowawczego przewidziane przez Kodeks wykroczeń;

- nałożyła 13030 grzywien w drodze mandatu karnego;

- skierowała 4898 wniosków o ukaranie do sądu.

Według Komendy Głównej Policji od ogłoszenia stanu zagrożenia epidemicznego i wprowadzenia związanych z tym ograniczeń, nakazów i zakazów szczególną wagę przykłada się do ich egzekwowania. Ma to bowiem na celu minimalizację rozprzestrzeniania się wirusa SARS-CoV-2 [56]. Jednak RPO rekomenduje, aby dotychczasowe kary nałożone na podstawie przepisów rozporządzeń wykraczających poza upoważnienia ustawowe zostały uchylone [57].

\section{Obowiazek zakrywania ust i nosa - przegylad wybranych krajów}

Wiele krajów wprowadziło obowiązek noszenia maseczek w miejscach publicznych pomimo sprzecznych opinii na temat tego, czy ich stosowanie może zapobiec przenoszeniu koronawirusa z jednej osoby na drugą. Pamiętać należy, że Światowa Organizacja Zdrowia, która zaleciła, aby zdrowi ludzie nie musieli nosić maski, a tylko ci, którzy źle się czują, kaszlą i kichają, a także opiekujący się osobą zarażoną [58], nie ułatwiła tym samym wprowadzenia nowych przepisów. Formalne wytyczne WHO stanowiły oficjalną poradę w wielu krajach (Francji, Niemczech, Włoszech, Luksemburgu), ale ponieważ temat bezobjawowego przenoszenia wirusa COVID-19 był coraz lepiej zbadany, rządy w tych krajach przekonały się do nakazu noszenia maseczek [59].

Istnieją wyraźne różnice w zasadach dotyczących tego, kto powinien nosić maskę publicznie, w zależności od roli i wieku. Osoby przebywające w miejscach publicznych ze względu na charakter swojej pracy (np. pracownicy sklepów lub policjanci), podobnie jak pracownicy służby zdrowia i opieki społecznej, podlegają innym zasadom dotyczącym noszenia maseczek i szerszego stosowania środków ochrony indywidualnej niż ogół społeczeństwa (chociaż w Polsce nie wprowadzono odrębnych przepisów dla tych grup). Z obowiązku zwolnione są czasami dzieci poniżej pewnego wieku - 2 lat w Czechach, 4 lat w Polsce, 6 lat we Włoszech i Izraelu oraz 12 lat w Belgii [59].

Wiele krajów zwiększyło krajową produkcję masek, aby zaspokoić popyt po wprowadzeniu nakazu lub udostępniło je w inny sposób. Przykładowo władze w Luksemburgu wręczyły po 50 masek każdemu obywatelowi w wieku powyżej 16 lat, a w Szwajcarii rząd rozdysponował 10 milionów masek do sprzedaży w supermarketach [59].

Podczas gdy w wielu krajach zakrywanie ust i nosa zostało wprowadzone w ramach środków przejściowych, czyli dopiero w czasie „odmrażania” (otwierania się) - przechodzenia do normalności (jak np. w Armenii, Belgii, Francji, Grecji, Hiszpanii, Holandii, Luksemburgu, na Łotwie, Malcie, w Niemczech, Portugalii, we Włoszech), w innych krajach noszenie maseczek było obowiązkowe poza domem w ramach środków przymusowego dystansowania się (np. w Austrii, Bułgarii, Izraelu, Polsce, Słowacji, Słowenii, na Węgrzech). W czasie „odmrażania” w niektórych krajach, jak Czechy czy Ukraina, nastąpiło rozluźnienie w przepisach, nakazujące noszenie maseczek tylko w transporcie publicznym lub tam, gdzie fizyczne dystansowanie nie jest możliwe (zob. rysunek 1). W Polsce również te przepisy zostały złagodzone, bowiem początkowo obowiązek zakrywania ust i nosa następował tuż po wyjściu z domu. Jednak w niektórych krajach zakrywanie ust i nosa było jedynie zalecane, ale nie obowiązkowe w ramach środków przejściowych (Gruzja, Szwajcaria, Wielka Brytania) [59].

Wytyczne WHO podkreślają szereg zagrożeń, które należy zrównoważyć, jeśli wprowadza się zalecenia 
Tabela 1. Zakrywanie ust i nosa - przepisy wybranych krajów

\begin{tabular}{|c|c|c|c|}
\hline Kraj & $\begin{array}{c}\text { Data wprowadzenia } \\
\text { obowiązku zakrywania } \\
\text { ust i nosa }\end{array}$ & Czy zakrywanie ust i nosa jest obowiązkowe? & $\begin{array}{l}\text { \% populacji noszących } \\
\text { maseczki w miejscach } \\
\text { publicznych }\end{array}$ \\
\hline Argentyna & 14.04 .2020 & Tak, w środkach transportu publicznego & bd \\
\hline Austria & 6.04 .2020 & Tak, w sklepach, aptekach oraz w transporcie publicznym & bd \\
\hline $\begin{array}{l}\text { Chińska Republika } \\
\text { Ludowa } \\
\text { Szanghaj }\end{array}$ & 8.02 .2020 & $\begin{array}{l}\text { Zalecane dla: ludzi w zatłoczonych miejscach, w miejscu pracy } \\
\text { ze stosunkowo gęstą populacją, ludzi udających się do placówek } \\
\text { medycznych, dzieci w przedszkolach i szkołach. } \\
\text { Tak, w miejscach publicznych }\end{array}$ & $88 \%$ \\
\hline Czechy & 19.03 .2020 & Tak, w przestrzeni publicznej & bd \\
\hline Dania & 15.06 .2020 & $\begin{array}{l}\text { Nie zaleca się noszenia przez zdrowe osoby. } \\
\text { Maski obowiązkowe na lotniskach }\end{array}$ & $5 \%$ \\
\hline Finlandia & & $\begin{array}{l}\text { Nie. Powszechne stosowanie masek na twarz ma niewielki lub } \\
\text { żaden wpływ na ograniczenie rozprzestrzeniania się infekcji } \\
\text { górnych dróg oddechowych }\end{array}$ & $7 \%$ \\
\hline Francja & 11.05 .2020 & $\begin{array}{l}\text { Tak, w transporcie publicznym dla osób powyżej 11. r.ż. oraz } \\
\text { w szkołach dla uczniów w wieku 11-15 lat }\end{array}$ & $56 \%$ \\
\hline Hiszpania & 4.05 .2020 & Tak, w środkach transportu publicznego dla osób powyżej 6. r.ż. & $72 \%$ \\
\hline Irlandia & 18.05 .2020 & $\begin{array}{l}\text { Tak, w zamkniętych przestrzeniach publicznych, w których } \\
\text { trudno utrzymać dystans społeczny }\end{array}$ & bd \\
\hline Izrael & 12.04 .2020 & Tak, w miejscach publicznych & bd \\
\hline Kanada & 6.04 .2020 & $\begin{array}{l}\text { Zalecane w sytuacjach, w których zachowanie dystansu jest } \\
\text { utrudnione }\end{array}$ & $41 \%$ \\
\hline Korea Południowa & 25.05 .2020 & Tak, w transporcie publicznym & bd \\
\hline Litwa & 10.04 .2020 & Tak, w miejscach publicznych & bd \\
\hline Luksemburg & 20.04 .2020 & $\begin{array}{l}\text { Tak, w miejscach, w których nie można zachować odstępu, jak } \\
\text { supermarkety czy transport publiczny }\end{array}$ & bd \\
\hline Niemcy & $\begin{array}{l}27.04 .2020 \text { (niektóre landy } \\
\text { wcześniej) }\end{array}$ & $\begin{array}{l}\text { Tak, w transporcie publicznym (w całym kraju), sklepach } \\
\text { i miejscach pracy (w większości landów) }\end{array}$ & $62 \%$ \\
\hline Norwegia & & $\begin{array}{l}\text { Nie. Maseczki są zalecane dla osób z podejrzeniem lub potwier- } \\
\text { dzonym zakażeniem, szczególnie podczas podróży do i ze szpi- } \\
\text { tala lub kliniki }\end{array}$ & $7 \%$ \\
\hline Polska & 16.04 .2020 & $\begin{array}{l}\text { Tak, w przestrzeni ogólnodostępnej dla osób powyżej 4. r.ż. } \\
\text { Dotyczy to terenów zielonych, takich jak parki i plaże, a także } \\
\text { miejsc publicznych, takich jak drogi, place, obiekty religijne, } \\
\text { obiekty handlowe i targowiska }\end{array}$ & bd \\
\hline $\begin{array}{l}\text { Republika Połu- } \\
\text { dniowej Afryki }\end{array}$ & \begin{tabular}{l|l|}
10.04 .2020 \\
1.05 .2020
\end{tabular} & $\begin{array}{l}\text { Zalecenie w miejscach w publicznych } \\
\text { Obowiązkowe w miejscach publicznych }\end{array}$ & bd \\
\hline Serbia & 29.06 .2020 & Tak, w miejscach publicznych & bd \\
\hline Singapur & 14.04 .2020 & Tak, w miejscach publicznych & bd \\
\hline Słowacja & \begin{tabular}{|l|}
15.03 .2020 \\
25.03 .2020 \\
\end{tabular} & $\begin{array}{l}\text { Tak, w transporcie publicznym i sklepach } \\
\text { Obowiązkowe w przestrzeni ogólnodostępnej }\end{array}$ & bd \\
\hline Słowenia & 29.03 .2020 & $\begin{array}{l}\text { Tak, wraz z rękawiczkami ochronnymi w pomieszczeniach } \\
\text { publicznych }\end{array}$ & bd \\
\hline Stany Zjednoczone & 18.06.2020 (11 stanów) & Tak, w większości miejsc publicznych & $63 \%$ \\
\hline Szwecja & & $\begin{array}{l}\text { Nie. Noszenie maseczek może stwarzać fałszywe poczucie } \\
\text { bezpieczeństwa, a publiczne używanie masek może wyrządzić } \\
\text { więcej szkody niż pożytku }\end{array}$ & $2 \%$ \\
\hline Turcja & 7.04 .2020 & Tak, w czasie zakupów i w zatłoczonych miejscach & bd \\
\hline Ukraina & 6.04 .2020 & Tak, w miejscach publicznych & bd \\
\hline Wietnam & 16.03 .2020 & Tak, w miejscach publicznych & $86 \%$ \\
\hline Włochy & 4.05 .2020 & $\begin{array}{l}\text { Tak, dla osób powyżej } 6 \text {. r.ż. w każdym zamkniętym miejscu } \\
\text { publicznym, w tym w środkach transportu publicznego oraz } \\
\text { kiedy nie można zachować bezpiecznego dystansu }\end{array}$ & $87 \%$ \\
\hline $\begin{array}{l}\text { Zjednoczone } \\
\text { Królestwo }\end{array}$ & 15.06 .2020 & Tak, w środkach transportu publicznego & $13 \%$ \\
\hline
\end{tabular}

Źródło: opracowanie własne. 
noszenia maseczek. Po pierwsze, noszenie maski może dawać ludziom fałszywe poczucie bezpieczeństwa, co z kolei może prowadzić do mniejszego przestrzegania innych ważnych środków zapobiegawczych, jak mycie rąk i dystans fizyczny. Po drugie, istnieje ryzyko samozanieczyszczenia maseczek, a więc być może ludzie nie będą potrafili z nich bezpiecznie korzystać. Po trzecie, w zależności od rodzaju maski, ich noszenie może powodować potencjalne trudności w oddychaniu [58]. Należy zatem zauważyć, że niektóre kraje odmówiły uwzględnienia polityk dotyczących noszenia maseczek w swoich podejściach (Dania, Estonia, Finlandia, Irlandia). W tabeli 1 zostały przedstawione podejścia wybranych krajów w odniesieniu do nakazu zakrywania ust i nosa.

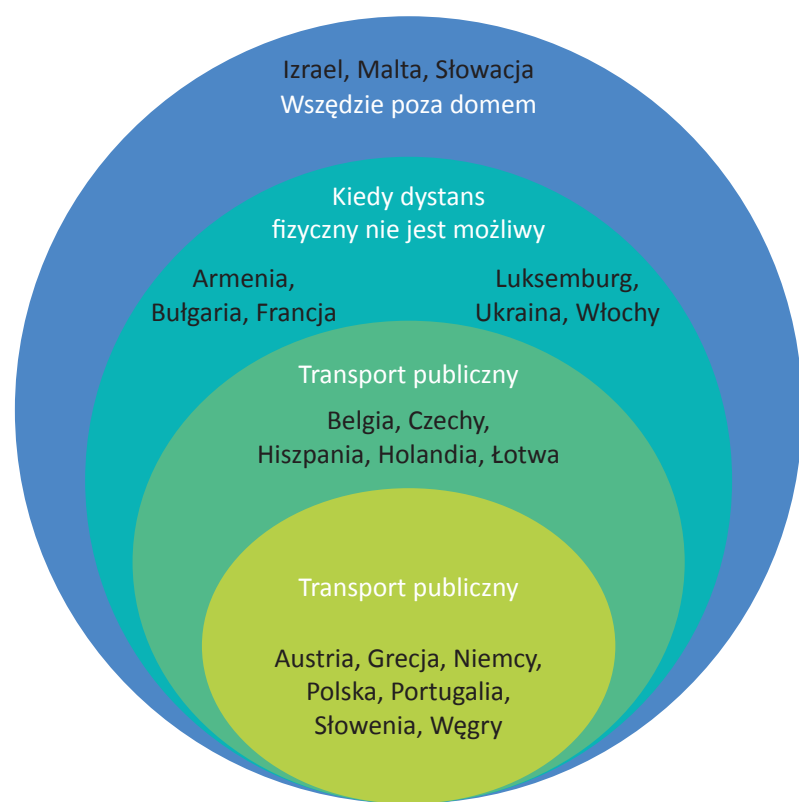

Rysunek 1. Obowiązek zakrywania ust i nosa w krajach europejskich w czasie „odmrażania”

Źródło: opracowanie na podstawie: E. Richardson, What Are the Policies on Wearing Facemasks in Public Places?, WHO, COVID-19 Health System Response Monitor, 2020, May 22, https://analysis.covid19healthsystem.org/index. php/2020/05/22/what-are-the-policies-on-wearing-facemasks-in-public-places/ (dostęp: 5.10.2020) [59].

\section{Zakończenie}

Liczba zakażonych koronawirusem i zgonów z powodu wirusa COVID-19 wciąż rośnie - potwierdzono już ponad $11,5 \mathrm{mln}$ przypadków zakażenia oraz ponad 500 tys. zgonów (stan na 7.07.2020) [60]. Systemy opieki zdrowotnej są w trudnej sytuacji, dlatego ,w obliczu pandemii poszukiwanie doskonałych dowodów (na skuteczność noszenia maseczek - K.B.-M.) może być wrogiem dobrej polityki. Maski są proste, tanie i potencjalnie skuteczne. (...) Noszone zarówno w domu (szczególnie przez osobę wykazującą objawy), jak i poza domem w sytuacjach, w których prawdopodobne jest spotkanie z innymi osobami (np. zakupy, transport publiczny), mogą mieć znaczący wpływ na transmisję i względnie niewielki wpływ na życie społeczne i gospodarcze" [61].

Maski mogą być zalecane lub obowiązkowe, medyczne lub niemedyczne, mogą mieć zastosowanie do różnych grup ludności, a zasady mogą się różnić w zależności od miejsca pobytu ludzi. Biorąc pod uwagę, że istnieją ograniczone dowody na skuteczność noszenia masek poza domem przez ogół społeczeństwa, należy monitorować i oceniać sytuację tam, gdzie taka polityka została wdrożona, abyśmy mogli zbudować bazę dowodową z korzyścią dla wszystkich. Badania będą musiały odzwierciedlać nie tylko skuteczność, ale także wszelkie wyzwania w zakresie akceptowalności i dostępności. Wszystkie polityki zostaną dostosowane do warunków lokalnych, ale nadal istnieje duże pole do nauki w różnych krajach.

\section{Przypisy}

${ }^{1}$ Dr Anthony Fauci, National Institute of Allergy and Infectious Diseases Director; Dr Robert Redfield, Centers of Disease Control and Prevention Director; Dr Stephen Hahn, Food and Drug Administration Commissioner.

${ }^{2}$ Dosłowny cytat: „Maseczki nie zabezpieczają przed wirusem, nie zabezpieczają przed zachorowaniem. Nie wiem, po co ludzie je noszą".

${ }^{3}$ Autorami opinii byli lek. Dariusz Tuleja i biolog dr Damian Ryszawy (afiliacji nie podano).

\section{Piśmiennictwo}

1. World Health Organization, Rolling updates on coronavirus disease (COVID-19), 2020, https://www.who.int/emergencies/ diseases/novel-coronavirus-2019/events-as-they-happen (dostęp: 5.10.2020).

2. West R., Michie S., Rubin J., Amlôt R., Don't touch the T-Zone - how to block a key pathway to infection with SARS-CoV-2, „BMJ Opinion” 2020, April 3, https://blogs.bmj.com/bmj/2020/04/03/dont-touch-the-t-zone-how-to-block-a-key-pathway-to-infection-with-sars-cov-2/ (dostęp: 5.10.2020).

3. Perski O., Simons D., West R., Michie S., Face masks to prevent community transmission of viral respiratory infections: A rapid evidence review using Bayesian analysis, „Qeios” 2020, doi:10.32388/1SC5L4, https://www.qeios.com/read/1SC5L4 (dostęp: 5.10.2020).

4. World Health Organization, Rational use of personal protective equipment for coronavirus disease (COVID-19) and considerations during severe shortages Interim guidance, 2020, April 6, https://apps.who.int/iris/bitstream/handle/10665/331695/ WHO-2019-nCov-IPC_PPE_use-2020.3-eng.pdf (dostęp: 5.10.2020).

5. Feng S., Shen C., Xia N., Song W., Fan M., Cowling B.J., Rational use offace masks in the COVID-19 pandemic, „The Lancet Respiratory Medicine", 2020, doi: 10.1016/S2213-2600(20)30134- X. 
6. National Health Service (UK), Are face masks useful for preventing coronavirus?, 2020, https://www.nhs.uk/conditions/coronavirus-covid-19/common-questions/ (dostęp: 5.10.2020).

7. World Health Organization, Shortage of personal protective equipment endangering health workers worldwide, 2020, March 3 , News release, Geneva, https://www.who.int/news-room/detail/03-03-2020-shortage-of-personal-protective-equipment-endangering-health-workers-worldwide (dostęp: 5.10.2020).

8. Postrel V., Pandemics Come and Go But Medical Masks Are Eternal, 2020, April 10, https://www.bloomberg.com/opinion/ articles/2020-04-10/medical-face-masks-an-illustrated-history (dostęp: 5.10.2020).

9. Mask, Wikipedia, https://en.wikipedia.org/wiki/Mask\#Medical (dostęp: 5.10.2020).

10. Freak A., Maska lekarza czasów pomoru, 24.08.2014, https://www.dobrystan.pl/artykuly/maska-lekarza-czasow-pomoru (dostęp: 5.10.2020).

11. Lee K.H., Wong D.T., Ho T.M., Ng K.H., Dr Wu Lien-teh: modernising post-1911 China's public health service, „Singapore Med J.” 2014; 55 (2): 99-102, doi:10.11622/smedj.2014025, https://www.ncbi.nlm.nih.gov/pmc/articles/PMC4291938/ (dostęp: 5.10.2020).

12. Strasser B.J., Schlich T., A history of the medical mask and the rise of throwaway culture, „The Lancet” 2020, July 4-10, Vol. 396, Issue 10243: 19-20, https://doi.org/10.1016/S0140-6736(20)31207-1, https:/www.thelancet.com/journals/lancet/article/ PIIS0140-6736(20)31207-1/fulltext (dostęp: 5.10.2020).

13. Wong T., Coronavirus: Why some countries wear face masks and others don't, BBC News, Singapore, 2020, May 12, https:// www.bbc.com/news/world-52015486 (dostęp: 5.10.2020).

14. Lynteris Ch., Why Do People Really Wear Face Masks During an Epidemic?, „The New York Times” 2020, February 13, https://www.nytimes.com/2020/02/13/opinion/coronavirus-face-mask-effective.html (dostęp: 5.10.2020).

15. Little B., When Mask-Wearing Rules in the 1918 Pandemic Faced Resistance, History Stories, 2020, May 6, https://www.history.com/news/1918-spanish-flu-mask-wearing-resistance (dostęp: 5.10.2020).

16. Cohn S., Face masks: What the Spanish flu can teach us about making them compulsory, The Conversation, 2020, May 1, https://theconversation.com/face-masks-what-the-spanish-flu-can-teach-us-about-making-them-compulsory-137648 (dostęp: 5.10.2020).

17. McGraw E., Everyone wore masks during the 1918 flu pandemic. They were useless, „The Washington Post” 2020, April 2, https:// www.Imtonline.com/news/article/Everyone-wore-masks-during-the-1918-flu-pandemic-15173632.php (dostęp: 5.10.2020).

18. Seladi-Schulman J., Can Face Masks Protect You from the 2019 Coronavirus? What Types, When and How to Use?, Healthline, 2020, June 2, https://www.healthline.com/health/coronavirus-mask\#takeaway (dostęp: 5.10.2020).

19. Centers for Disease Control and Prevention, Use of Cloth Face Coverings to Help Slow the Spread of COVID-19. Sew and No Sew Instructions, https://www.cdc.gov/coronavirus/2019-ncov/prevent-getting-sick/diy-cloth-face-coverings.html (dostęp: 5.10.2020)

20. Centers for Disease Control and Prevention, Recommendation Regarding the Use of Cloth Face Coverings, Especially in Areas of Significant Community-Based Transmission, https://www.cdc.gov/coronavirus/2019-ncov/prevent-getting-sick/clothface-cover.html (dostęp: 5.10.2020).

21. Maska, ale jaka? Szybki test z aerozolem w ręku, TVN Meteo, 11.04.2020, https://tvnmeteo.tvn24.pl/informacje-pogoda/polska,28/maska-ale-jaka-szybki-test-z-aerozolem-w-reku,319491,1,0.html (dostęp: 5.10.2020).

22. Food and Drug Administration, N95 Respirators and Surgical Masks (Face Masks), 2020, August 20, https://www.fda.gov/medical-devices/personal-protective-equipment-infection-control/n95-respirators-and-surgical-masks-face-masks (dostęp: 5.10.2020).

23. Dhouibi H., Surgical Masks, Respirators, Barrier Masks: Which Masks Actually Protect Against Coronavirus?, MedicalExpo e-Magazine, 2020, February 28, http://emag.medicalexpo.com/which-masks-actually-protect-against-coronavirus/ (dostęp: 5.10.2020).

24. Koronawirus (COVID-19) a maseczki ochronne - czym się różnią?, Medicover, Biblioteka Zdrowia, 2020, https://www.medicover.pl/o-zdrowiu/koronawirus-covid-19-a-maseczki-ochronne-czym-sie-roznia,6861,n,192 (dostęp: 5.10.2020).

25. European Centre for Disease Prevention and Control, Cloth masks and mask sterilisation as options in case of shortage of surgical masks and respirators. Technical report, Stockholm, 2020, March 26, https://www.ecdc.europa.eu/sites/default/files/ documents/Cloth-face-masks-in-case-shortage-surgical-masks-respirators2020-03-26.pdf (dostęp: 5.10.2020).

26. Unia Europejska, Dyrektywa Rady z dnia 21 grudnia 1989 r. w sprawie zbliżenia ustawodawstw Państw Członkowskich odnoszących się do wyposażenia ochrony osobistej (89/686/EWG), https://eur-lex.europa.eu/legal-content/PL/TXT/PDF/?uri=CE LEX:31989L0686\&from=EN (dostęp: 5.10.2020).

27. 3M, Comparison of FFP2, KN95, and N95 and Other Filtering Facepiece Respirator Classes, Technical Bulletin. Revision 3 , 2020, May, https:/multimedia.3m.com/mws/media/1791500O/comparison-ffp2-kn95-n95-filtering-facepiece-respirator-classestb.pdf (dostęp: 5.10.2020).

28. North A., What Trump's refusal to wear a mask says about masculinity in America, Vox, 2020, May 12, https://www.vox. com/2020/5/12/21252476/masks-for-coronavirus-trump-pence-honeywell-covid-19 (dostęp: 5.10.2020).

29. CGTN, Report: Trump refuses to wear mask to avoid harming re-election chances, 2020, May 10, https://news.cgtn.com/news/202005-10/Trump-refuses-to-wear-mask-to-avoid-harming-re-election-chances--QnEtzuj7ff/index.html (dostęp: 5.10.2020).

30. Herman S., White House Staffers Told to Wear Masks, COVID-19 Pandemic, 2020, May 11, https://www.voanews.com/covid19-pandemic/white-house-staffers-told-wear-masks (dostęp: 5.10.2020). 
31. Ulanowski T., Uczony, który w Chinach dowodzi walka z koronawirusem: „Popetniacie bład w USA i Europie”, Wyborcza.pl, 1.04.2020, https://wyborcza.pl/7,75400,25832669,wszyscy-musza-nosic-maseczki-zakazonych-koronawirusem-nawet.html (dostęp: 5.10.2020).

32. McMaster University, Evidence shows cloth masks may help against COVID-19: Particularly those with several layers of cotton cloth, „Science Daily” 2020, May 26, https://www.sciencedaily.com/releases/2020/05/200526115044.htm (dostęp: 5.10.2020).

33. KG, Szumowski o koronawirusie: maseczki nie pomagają. Nie wiem, czemu ludzie je nosza, RMF FM/Rynek Zdrowia, 26.02.2020, https://www.rynekzdrowia.pl/Uslugi-medyczne/Szumowski-o-koronawirusie-maseczki-nie-pomagaja-Nie-wiem-czemu-ludzie-je-nosza,203278,8.html (dostęp: 5.10.2020).

34. Szumowski o koronawirusie: Maseczki nie pomagaja, RMF FM, Interia.pl, 26.02.2020, https://m.interia.pl/interia-tv/ video,vId,2845245 (dostęp: 5.10.2020).

35. Rozporządzenie Rady Ministrów z dnia 15 kwietnia 2020 r. w sprawie obowiązku zakrywania ust i nosa w miejscach publicznych (Dz.U. z 15 kwietnia 2020 r., poz. 673).

36. PAP, Koronawirus w Polsce. Resort zdrowia przypomina o obowiazku noszenia maseczek, PolskieRadio24.pl, 14.05.2020, https://polskieradio24.p1/5/1222/Artyku1/2510222,Koronawirus-w-Polsce-Resort-zdrowia-przypomina-o-obowiazku-noszenia-maseczek (dostęp: 5.10.2020).

37. PAP, Szumowski: Od 16 kwietnia obowiazek zakrywania nosa i ust, Dziennik.pl, 9.04.2020, https://wiadomosci.dziennik.pl/ polityka/artykuly/6480817,szumowski-maseczka-koronawirus-covid-19-epidemia-usta-zdrowie.html (dostęp: 5.10.2020).

38. Ceglarz J., Koronawirus w Polsce. Maseczki obowiązowe do czasu wynalezienia szczepionki, Money.pl, 16.04.2020, https://www.money.pl/gospodarka/koronawirus-w-polsce-maseczki-obowiazkowe-do-czasu-wynalezienia-szczepionki-6500573425690753a.html (dostęp: 5.10.2020).

39. Jurkiewicz K., Do kiedy obowiązek noszenia maseczek? Szokująca odpowiedź ministra Szumowskiego. Może chodzić nawet o 2 lata, „Dziennik Zachodni” 2020, 5.05, https://dziennikzachodni.pl/do-kiedy-obowiazek-noszenia-maseczek-szokujaca-odpowiedz-ministra-szumowskiego-moze-chodzic-nawet-o-2-lata/ar/c1-14922200 (dostęp: 5.10.2020).

40. Świdrak K., Dlaczego wszyscy powinni nosić maseczki na twarz? Naukowcy thumacza, Medonet, 29.05.2020, https://www.onet. $\mathrm{pl} /$ ?utm_source=www.medonet.pl_viasg_medonet\&utm_medium=referal\&utm_campaign=leo_automatic\&srcc $=\mathrm{ucs} \& \mathrm{pid}=\mathrm{d} 9 \mathrm{f} 31 \mathrm{c} 4 \mathrm{f}-$ b8d3-4305-802f-aad465105a4e\&sid=4e9b6959-4f88-4e8b-9613-65de7438fe5a\&utm_v=2 (dostęp: 5.10.2020).

41. „Maseczkowi spekulanci” zarabiają na dezinformacji. Padają rekordy..., Mgr.farm, 26.02.2020, https://mgr.farm/aktualnosci/ maseczkowi-spekulanci-zarabiaja-na-dezinformacji-padaja-rekordy/ (dostęp: 5.10.2020).

42. KarwowskaA., Włosi umieraja, bo zareagowaliza późno, Wyborcza.pl,28.02.2020, https://wyborcza.pl/7,162657,25735467,wlosi-umieraja-bo-zareagowali-za-pozno.html (dostęp: 5.10.2020).

43. Prof. Włodzimierz Gut: nie panikujmy z powodu koronawirusa, Sygnały dnia, Jedynka Polskie Radio, 2.03.2020, https://www. polskieradio24.p1/7/129/Artykul/2465617,Prof-Wlodzimierz-Gut-nie-panikujmy-z-powodu-koronawirusa (dostęp: 5.10.2020).

44. Dadura K., Wirusolog obala mity na temat koronawirusa. „Maseczka może być źródtem zakażeń”, PolskieRadio24.pl, 6.03.2020, https://www.polskieradio24.p1/5/1222/Artykul/2467271, Wirusolog-obala-mity-na-temat-koronawirusa-Maseczka-moze-byc-zrodlem-zakazen (dostęp: 5.10.2020).

45. Wirusolog prof. Gut o sensie stosowania maseczek. Ich skuteczność jest krótkotrwała, PCh24.pl, 13.05.2020, https://www.pch24. pl/wirusolog-prof--gut-o-sensie-stosowania-maseczek--ich-skutecznosc-jest-krotkotrwala,75563,i.html (dostęp: 5.10.2020).

46. Sokołowska A., Maseczki ochronne. Czy ich noszenie ma sens? Wirusolog Włodzimierz Gut wyjaśnia, Wirtualna Polska. Kobieta, 17.04.2020, https://kobieta.wp.pl/maseczki-ochronne-czy-ich-noszenie-ma-sens-wirusolog-wlodzimierz-gut-wyjasnia-6500789009070209a (dostęp: 5.10.2020).

47. Nowe zasady zastaniania nosa $i$ ust, otwarte kina i siłownie - wchodzimy w kolejny etap odmrażania, Gov.pl, 27.05.2020, https://www.gov.pl/web/koronawirus/4-etap-odmrazania (dostęp: 5.10.2020).

48. Rozporządzenie Rady Ministrów z dnia 10 kwietnia 2020 r. w sprawie ustanowienia określonych ograniczeń, nakazów i zakazów w związku z wystąpieniem stanu epidemii (Dz.U. z 2020 r., poz. 658), http://dziennikustaw.gov.pl/D2020000065801.pdf (dostęp: 5.10.2020).

49. Rozporządzenie Rady Ministrów z dnia 15 kwietnia 2020 r. zmieniające rozporządzenie w sprawie ustanowienia określonych ograniczeń, nakazów i zakazów w związku z wystąpieniem stanu epidemii (Dz.U. z 2020 r., poz. 673), http://dziennikustaw. gov.p1/D2020000067301.pdf (dostęp: 5.10.2020).

50. Rozporządzenie Rady Ministrów z dnia 2 maja 2020 r. w sprawie ustanowienia określonych ograniczeń, nakazów i zakazów w związku z wystąpieniem stanu epidemii (Dz.U. z 2020 r., poz. 792), http://dziennikustaw.gov.pl/D2020000079201.pdf (dostęp: 5.10.2020).

51. Obowiazek zastaniania ust i nosa przez wszystkich nie ma podstawy prawnej, Dogmaty Karnisty, 4.05.2020, https://www. dogmatykarnisty.p1/2020/05/obowiazek-zaslaniania-ust-i-nosa/ (dostęp: 5.10.2020).

52. Ustawa z dnia 5 grudnia 2008 r. o zapobieganiu oraz zwalczaniu zakażeń i chorób zakaźnych u ludzi (Dz.U. z 2008 r. Nr 234 , poz. 1570), https://isap.sejm.gov.pl/isap.nsf/download.xsp/WDU20082341570/U/D20081570Lj.pdf (dostęp: 5.10.2020).

53. Rzecznik Praw Obywatelskich, Koronawirus. Rozporządzenie rządu z 31 marca o ograniczeniach poruszania się - krytyczna ocena RPO, 3.04.2020, https:/www.rpo.gov.pl/pl/content/koronawirus-rozporzadzenie-rzadu-z-31-marca-krytyczna-ocena-rpo\%C2\%A0 (dostęp: 5.10.2020).

54. Rzecznik Praw Obywatelskich, Analiza RPO dla premiera o tworzeniu prawa $w$ stanie epidemii: rozporzadzenia zamiast ustaw naruszaja prawa obywateli, 4.06.2020, https://www.rpo.gov.pl/pl/content/raport-rpo-dla-premiera-nt-prawa-w-stanie-epidemii (dostęp: 5.10.2020). 
55. Sygn. Akt II W 71/20. Postanowienie z dnia 3 czerwca 2020 r. Sąd Rejonowy w Kościanie.

56. Pieniążek-Osińska B., Policja wystawiła 13 tys. mandatów za brak maseczki, Polityka Zdrowotna, 10.06.2020, https://www. politykazdrowotna.com/60364,ile-mandatow-za-brak-maseczki-wystawila-policja (dostęp: 5.10.2020).

57. Rzecznik Praw Obywatelskich, Pismo do Prezesa RM w sprawie naruszenia praw $i$ wolności w czasie pandemii, Warszawa, 4.06.2020, https://www.rpo.gov.pl/sites/default/files/do\%20Prezesa\%20RM\%20ws\%20naruszania\%20praw\%20i\%20 wolno\%C5\%9Bci\%20w\%20czasie\%20pandemii\%2C\%204.06.2020_0.pdf (dostęp: 5.10.2020).

58. World Health Organization, Advice on the use of masks in the context of COVID-19, Interim guidance, 2020, June 5, WHO reference number: WHO/2019-nCov/IPC_Masks/2020.4, https://www.who.int/publications/i/item/advice-on-the-use-of-masksin-the-community-during-home-care-and-in-healthcare-settings-in-the-context-of-the-novel-coronavirus-(2019-ncov)-outbreak (dostęp: 5.10.2020).

59. Richardson E., What Are the Policies on Wearing Facemasks in Public Places?, WHO, COVID-19 Health System Response Monitor, 2020, May 22, https://analysis.covid19healthsystem.org/index.php/2020/05/22/what-are-the-policies-on-wearingfacemasks-in-public-places/ (dostęp: 5.10.2020).

60. COVID-19 Dashboard by the Center for Systems Science and Engineering (CSSE) at JHU, https://gisanddata.maps.arcgis. com/apps/opsdashboard/index.html\#/bda7594740fd40299423467b48e9ecf6 (dostęp: 5.10.2020).

61. Greenhalgh T., Schmid M.B., Czypionka T., Dirk B., Laurence G., Face masks for the public during the covid-19 crisis, „BMJ” 2020; 369, https://www.bmj.com/content/369/bmj.m1435 (dostęp: 5.10.2020). 